\title{
116. The Activity of Alkaline Phosphatase in the Oviducal Epithelium of the Newt, Triturus pyrrhogaster, Injected with Estriol, Diethylstilbestrol, Estrone, Testosterone or Desoxycorticosterone Acetate, Singly or in Combination with Progesterone
}

\author{
By Shunichi Kambara \\ Zoological Institute, Faculty of Science, University of Tokyo \\ (Comm. by Yô K. OKada, M.J.A., Sept. 1964)
}

In a previous paper, the writer (1962) has reported that injections of progesterone for a prolonged period is not effective in causing the development of the oviducts of ovariotomized newts, although it stimulates the activity of alkaline phosphatase in the epithelial cells of the oviducts. In a later paper (Kambara, 1963c), it has been shown that progesterone is similarly effective in provoking the activation of the enzyme in the oviducal epithelium of hypophysectomizedovariotomized newts. Accordingly, it seems highly probable that in the newts, progesterone may directry activate alkaline phosphatase in the oviduct, without mediation of the anterior pituitary. Under natural conditions, alkaline phosphatase becomes active in the epithelium of the oviducts only during the breeding season. This fact may suggest that the enzyme plays a role in the secretion of the jelly substance by the oviducts at the time of oviposition (Kambara, 1956 a, $1963 \mathrm{a}, \mathrm{b})$.

According to Wright $(1961 \mathrm{~b})$, the ovulation-inducing effect of progesterone on ovarian fragments of Rana pipiens was enhanced by estrogen, whereas similar effect of pituitary implants was impaired by estrogen. On the basis of these findings, Wright conjectured that estrogen might inhibit the biosynthesis of some ovulatory steroids but augment the action of ovulatory steroids once they are formed.

The present communication deals with the effects of some steroids on the activation of alkaline phosphatase in the epithelial cells of the oviducts by progesterone in ovariotomized newts.

Material and methods. Materials used and general procedures of the present series of experiments were almost similar to those reported previously (Kambara, 1963c). Seventy-two adult females of the newt, Triturus pyrrhogaster, were ovariotomized through a ventral incision under light ether anesthesia, on April 17 and 18, 1964. Beginning on the 37 th day after operation, animals were injected intraperitoneally with $0.1 \mathrm{mg}$ of hormonic substance suspended in 0.1 cc of a $0.8 \% \mathrm{NaCl}$ solution, once a week for five successive weeks. 
All animals were sacrificed between June 29 and July 1, 7 to 10 days after the last injection. Immediately after being killed by decapitation, the animals were weighed. The oviducts were dissected out, carefully freed from extraneous tissues and weighed. From each oviduct, a piece from the middle portion, i.e. the so-called "watery" secretory region (Kambara, 1956a), was excised and fixed in cold absolute acetone for 2 to 3 hours. Sections were cut in paraffin at $6 \mu$. For histochemical demonstration of alkaline phosphatase, materials were treated according to the calcium-cobalt method of Gomori (1941). Sections were incubated for 2 hours at $37^{\circ} \mathrm{C}$ in a mixture consisting of $400 \mathrm{mg}$ of sodium $\beta$-glycerophosphate, $400 \mathrm{mg}$ of sodium diethyl barbital, $4 \mathrm{ml}$ of $2 \% \mathrm{CaCl}_{2}$ solution, $2 \mathrm{ml}$ of $2 \% \mathrm{MgCl}_{2}$ solution and $80 \mathrm{ml}$ of deionized water. For the purpose of comparison, another series of sections were treated by the modified coupling azo method after Pearse (1961). Sections were incubated for 1 hour at $20^{\circ} \mathrm{C}$, in a mixture of $50 \mathrm{mg}$ of sodium $\alpha$-naphthyl phosphate and $100 \mathrm{mg}$ of Fast Red TR dissolved in $100 \mathrm{ml}$ of "tris" buffer ( $\mathrm{pH} .9 .8$ ).

Observation and discussion. The distribution and activity of the enzyme in the epithelial cells of the oviduct demonstrated by the azo-dye method, with sodium $\alpha$-naphthyl phosphate as substrate, was essentially the same as those shown by Gomori's method.

The oviducts of both progesterone-injected (lot 2) and non-injected ovariotomized newts (lot 1), were quite atrophic, the epithelial cells being reduced in size, having a small amount of cytoplasm. In noninjected newts, the epithelium of the oviducts exhibited only a very

Effects of various hormones on the weight of the oviducts and on the activity of alkaline phosphatase in the epithelial cells of the oviduct of ovariotomized newts

\begin{tabular}{|c|c|c|c|c|c|c|c|}
\hline \multirow{2}{*}{ Lot } & \multirow{2}{*}{ Injected material } & \multirow{2}{*}{$\begin{array}{c}\text { Average weight } \\
\text { of oviducts } \\
\text { (mg/g. body wt.) }\end{array}$} & \multicolumn{5}{|c|}{ Phosphatase activity } \\
\hline & & & H & $H$ & + & \pm & - \\
\hline 1 & none & 18.6 & & & 3 & 2 & 1 \\
\hline 2 & progesterone & 18.7 & 1 & 21 & 1 & & 1 \\
\hline 3 & estriol & 26.4 & 2 & 3 & 1 & & \\
\hline 4 & estriol + progesterone & 26.7 & & 1 & 13 & & 1 \\
\hline 5 & $\mathrm{DES}$ & 27.2 & & & 1 & 2 & 3 \\
\hline 6 & DES+progesterone & 29.8 & & & 12 & 3 & \\
\hline 7 & estrone & 29.1 & 1 & 1 & 3 & 1 & \\
\hline 8 & estrone + progesterone & 25.4 & & 1 & 4 & 1 & \\
\hline 9 & testosterone & 30.4 & 2 & 2 & 1 & 1 & \\
\hline 10 & testosterone + progesterone & 28.3 & 2 & 12 & & 1 & \\
\hline 11 & DCA & 21.2 & & 2 & 2 & 1 & 1 \\
\hline 12 & DCA+ progesterone & 23.8 & 2 & 2 & 2 & & \\
\hline
\end{tabular}


weak reaction of the enzyme (lot 1), if any, while in a majority of those given injections of progesterone, the activity of alkaline phosphatase in the epithelial cells of the oviducts was markedly enhanced (lot 2). These findings are in good agreement with those reported previously (Kambara, 1962, 1963c). In a majority of cases receiving injections of estriol or testosterone, the oviducts were increased in relative weight and showed a definitely stronger reaction of alkaline phosphatase in the cytoplasm of the epithelial cells, as compared with that in non-injected ovariotomized animals (lots 3 and 9). In those which had received injections of estrone, although the oviducts were greatly increased in relative weight (lot 7), the stimulation of the enzyme activity was much less marked than in animals given injections of the other steroids.

Injections of diethylstilbestrol (DES) brought about an increase in the oviducal weight but failed to provoke any significant increase in the reaction of alkaline phosphatase over that in the ovariotomized, non-injected controls (lot 5). However, this fact does not necessarily indicate that DES-injections are not capable of activating the enzyme in the epithelium of the oviducts. As mentioned previously (Kambara, 1959), following administration of the enough amount of DES for a period of sufficient length, a positive reaction of the enzyme might be demonstrated in the cytoplasm of the epithelial cells.

After injections of desoxycorticosterone acetate (DCA), the cytoplasm of the epithelial cells of the oviducts exhibited a moderate reaction of the enzyme, although the growth of the oviducts was scarcely stimulated (lot 11).

In newts given simultaneous injections of testosterone and progesterone (lot 10), the reaction of phosphatase in the oviducal epithelium was as strong as that in animals receiving injections of testosterone alone. The combination of estrone and progesterone (lot 8) caused an activation of the enzyme in the oviduct in almost similar manner to estrone (lot 7).

According to Wright (1961 b), the ovulation-inducing action of progesterone on ovarian fragments from the autumn frogs, Rana pipiens, was enhanced by estrogens. However, Edgren and Carter (1963) who carried out similar experiments in July, reported that neither estrone nor testosterone significantly modified the ovulationinducing faculty of progesterone in Rana pipiens. The latter authors attributed the discrepancies between the findings of Wright and their own to seasonal differences in responsiveness of ovarian fragments to steroids. The present experiments were carried out during the breeding season of the newt, from April to June, like those of Edgren and Carter on the frogs. According to these authors, estriol, but 
not estrone, blocked the stimulation of ovulation by progesterone in Rana ovarian fragments. In the present experiments, estriol was very effective in activating the alkaline phosphatase in the oviducal epithelium (lot 3), while a combination of estriol and progesterone was much less active in this respect. It is not known whether estriol inhibits the action of progesterone on the enzyme system or progesterone blocks the activation of the enzyme by estriol. Edgren and Carter have not yet reported the effect of estriol on the ovulation in the absence of progesterone.

The oviducal epithelium of a majority of the newts injected with DCA showed a moderate reaction of alkaline phosphatase (lot 11), but if progesterone was injected concurrently with DCA, the enzyme activity was decidedly increased (lot 12). For these findings, at least two possible explanations suggest themselves: (1) The activating effect of DCA on the enzyme was increased in the presence of progesterone or (2) the increase in the enzyme activity was caused by progesterone, DCA being without effect. Estriol, DES and estrone seem to have attenuated the effect of progesterone on the enzyme activity in the oviducal epithelium. In contrast, testosterone and DCA were incapable of blocking the effect of progesterone.

It has been shown by previous workers that estrogen given alone cannot induce ovulation in both Rana pipiens (Langan, 1941; Wright, 1961 a) and Triturus pyrrhogaster (Kambara, 1954). The failure of estrogens to induce ovulation was attributed to their inhibitory effects on the ovarian synthesis of ovulatory steroids, e.g. progesterone (Wright, $1961 \mathrm{~b}$ ). It is widely accepted that estrogen antagonizes the physiological actions of progesterone (see Wright, $1961 \mathrm{~b})$. Therefore, the inhibitory effect of estrogens on the alkaline phosphatase in the oviducal epithelium by progesterone may be explained on this basis. Although estrogens are not effective in inducing ovulation, they could activate alkaline phosphatase in the epithelial cells of the oviducts.

Summary. In'ovariotomized adult newts, Triturus pyrrhogaster, were given intraperitoneal injections of estriol, DES, estrone, testosterone or DCA, singly or in combination with progesterone, and the activity of alkaline phosphatase in the epithelial cells of the oviducts was studied histochemically. After injections of progesterone, estriol, estrone, testosterone or DCA for a prolonged period, the cytoplasm of the epithelial cells of the oviducts exhibited a strong or moderate reaction of alkaline phosphatase in a majority of cases, while following injections of DES, the cells showed only a weak reaction of the enzyme. Under the conditions of the present experiments, estriol, DES and estrone attenuated the enzyme-activating faculty of pro- 
gesterone, while testosterone and DCA were without effect in this respect. The findings were discussed in relation to the effects of progesterone and other steroids on the ovulation in amphibians.

Acknowledgements. I wish to thank Dr. Yô K. Okada of National Museum of Natural Science and Prof. K. Takewaki of Tokyo University for their kind criticism and encouragement during the course of the present experiment.

\section{References}

Edgren, R. A., and D. L. Carter (1963): Gen. Comp. Endocr., 3, 526.

Gomori, G. (1941): Jour. Cell. Comp. Physiol., 17, 71.

Kambara, S. (1954): Annot. zool. Japan, 27, 180.

- (1956): Ibid., 29, 86.

- (1959): Ibid., 32, 65.

—_ (1962): Zool. Mag., 71, 328.

- (1963a): Jour. Fac. Sci., Univ. Tokyo, IV, 10, 189.

(1963b): Zool. Mag., 72, 271.

- (1963c): Proc. Japan Acad., 39, 600.

Langan, W. B. (1941): Proc. Soc. Exptl. Biol. Med., 47, 59.

Pearse, A. G. E. (1960): Histochemistry Theoretical and Applied. 2nd. Ed., J. \& A. Churchill, Ltd. London.

Wright, P. (1961a): Gen. Comp. Endocr., 1, 20.

— (1961b): Ibid., 1, 381. 